\title{
QuantiFERON-TB Gold In-Tube TEST IN THE DIAGNOSIS OF LATENT TUBERCULOSIS INFECTION IN ARTHRITIS PATIENTS TREATED WITH TUMOR NECROSIS FACTOR ANTAGONISTS
}

\author{
Denis Baričević ${ }^{1}$, Sanja Popović Grle ${ }^{1}$, Jadranka Morović Vergles² ${ }^{2}$ Silvija Čuković Čavka ${ }^{3}$, \\ Marko Jakopović ${ }^{1}$, Gzim Redžepi ${ }^{1}$, Zagorka Boras ${ }^{1}$, Marinka Baričevićc ${ }^{4}$ and Miroslav Samaržija ${ }^{1}$ \\ ${ }^{1}$ Jordanovac Clinical Department of Respiratory Diseases, Zagreb University Hospital Centre; \\ ${ }^{2}$ Clinical Department of Internal Medicine, Dubrava University Hospital; \\ ${ }^{3}$ Department of Gastroenterology, Clinical Department of Internal Medicine, Zagreb University Hospital Centre; \\ ${ }^{4}$ Dental Practice, Zagreb-West Health Center, Zagreb, Croatia
}

\begin{abstract}
SUMMARY - The aim of this study was to investigate the role of the QuantiFERON-TB Gold In-Tube test (QFT-GIT) in detecting latent tuberculosis in immunocompromised patients before introducing tumor necrosis factor (TNF- $\alpha$ ) antagonists. The study included 300 subjects of similar age. The study group comprised of 150 QuantiFERON (QFT) positive subjects with rheumatoid arthritis, Crohn's disease, ulcerative colitis, ankylosing spondylitis and psoriatic arthritis, while control group comprised of 150 QFT negative respondents with the same diseases. Exhaustive medical history was documented for all patients. Screening tests were performed including QFT-GIT, tuberculin skin test (TST), chest radiography and detection of Mycobacterium tuberculosis in sputum culture 2 times. A positive QFT-GIT test result, regardless of TST result, was considered as an indication for latent tuberculosis infection (LTBI) treatment. Results of this study showed good correlation between the conclusive results of QFT-GIT and TST. All study group patients had normal clinical findings, normal radiologic findings and negative results of sputum microbiological analysis during the course of prophylaxis and after its completion and during the course of biological therapy. Conversion of positive QFT-GIT test to negative was observed in $4 \%$ of study group patients, while QFT negative respondents remained negative. There was a statistically significant positive correlation between QFTGIT, TST results and patient age, smoking habit and contact with tuberculosis. Study results showed that along with good clinical evaluation and detailed medical history, it is important to conduct testing in order to avoid disease progression or unnecessary isoniazid prophylaxis.
\end{abstract}

Key words: Tuberculin test; Latent tuberculosis - diagnosis; Arthritis; Tumor necrosis factors - antagonists and inhibitors; Biological therapy; Croatia

\section{Introduction}

Since tuberculosis is associated with tumor necrosis factor alpha $(\mathrm{TNF}-\alpha)$ blockade, the widespread use of TNF- $\alpha$ antagonists for inflammatory diseases has led

Correspondence to: Denis Baričevic, $M D$, Jordanovac Clinical Department of Respiratory Diseases, Zagreb University Hospital Centre, Jordanovac 104, HR-10000 Zagreb, Croatia

E-mail: denis.baricevic@kbc-zagreb.hr

Received April 26, 2016, accepted July 14, 2016 to an increased rate of active tuberculosis cases ${ }^{1}$. Arthritis patients are at a higher risk of infection because of the disease and immunosuppressive therapies, including prednisolone, disease-modifying anti-rheumatic drugs (DMARDs) and TNF- $\alpha$ antagonists ${ }^{2,3}$. Most biologics appear to be similar in their propensity to promote serious infection ${ }^{4}$.

Latent tuberculosis infection (LTBI) is the presence of Mycobacterium tuberculosis (TB) without any 
symptoms of active disease. Detection of LTBI is important in clinical practice due to its associated risk of progression to active disease, especially in immunocompromised population ${ }^{1}$.

There are no clinical symptoms and signs in LTBI and no gold standard laboratory test is available. Until recently, the tuberculin skin test (TST) was the only test available for diagnosing LTBI. The sensitivity and specificity of TST are considered generally low, under $100 \%$, with the occurrence of false-negative results due to depressed immunity and false-positive results due to previous Bacillus Calmette-Guérin (BCG) immunization and cross-reactivity with opportunistic mycobacteria. It also has limitations including a significant false-positive rate and poor sensitivity in immunocompromised individuals ${ }^{2,5,6}$. Another available test for detection of LTBI is QuantiFERON-TB Gold InTube (QFT-GIT) test, which has been demonstrated to have comparable sensitivity to TST for LTBI, but its strength appears to be in its superior specificity, particularly in BCG-vaccinated population and its better correlation with the known TB risk factors.

It seems to offer better possibility of improved detection of LTBI, however, data on its performance in arthritis patents are limited ${ }^{5-13}$.

This article reviews the role of the QFT-GIT test in the diagnosis of latent tuberculosis infection in arthritis patients prior and during TNF- $\alpha$ antagonist therapy.

\section{Patients and Methods}

During one-year study period, 300 patients underwent treatment with TNF- $\alpha$ antagonists. The study group comprised of 150 QuantiFERON (QFT) positive patients (mean age, 51.8; 82 women and 68 men) suffering from rheumatoid arthritis, Crohn's disease, ulcerative colitis, ankylosing spondylitis and psoriatic arthritis, while control group comprised of 150 QFT negative respondents (mean age, 45.98; 75 women and 75 men) with the same diseases. Exhaustive medical history was documented for all subjects. A pre-structured questionnaire on comorbidity, drug intake, family history of tuberculosis, epidemiological history (tuberculosis contact, country of birth), occupation, BCG immunization, smoking habits and alcohol consumption was filled out for each subject.
During the first clinical examination, both QFTGIT (QFT-GIT test; Cellestis Ltd., Carnegie, Victoria, Australia) and TST were performed. The QFTGIT test was performed according to the manufacturer's instructions and positive test result was defined as $\geq 0.35 \mathrm{IU} / \mathrm{mL}$, while the TST was performed using the Mantoux method with 2 tuberculin units (TU) of purified protein derivative RT23 (Statens Serum Institute, Copenhagen, Denmark) on the volar side of the forearm. Induration size was measured after 48-72 hours, while $10-\mathrm{mm}$ induration was positive cut-off value for the TST.

To rule out active disease in all subjects, detailed clinical evaluation included physical examination, chest radiographs and microbiological analysis for Mycobacterium tuberculosis (sputum culture 2 times).

In subjects with positive QFT-GIT test regardless of TST result and normal chest radiographs and negative microbiological examination, 6-month prophylaxis with isoniazid was introduced, whereas TNF- $\alpha$ antagonist treatment was initiated 6 weeks after isoniazid introduction. In QFT negative subjects, TNF- $\alpha$ antagonist treatment was introduced immediately. TST was administered 3 days prior to QFT-GIT to rule out inaccurate results, since TST appeared to affect QFT-GIT responses, especially in QFT-GIT negative subjects but only after 3 days and may apparently persist for several months, although with scarce evidence ${ }^{14}$.

In all subjects, second clinical evaluation was performed six months after the first visit and included physical examination and chest radiographs, while third clinical evaluation was performed after one year and included physical examination, chest radiographs, microbiological analysis for Mycobacterium tuberculosis (sputum culture 2 times) and QFT-GIT test.

\section{Ethics}

Prior to signing a written consent, each patient was thoroughly informed about the purpose of the study. The study was approved by the Ethics Committee, School of Medicine, University of Zagreb.

\section{Statistics}

Statistical analysis was performed using the STATISTICA 12.0 software package (StatSoft, Inc., USA). Basic statistical parameters for continuous vari- 
ables and frequency tables for categorical variables were calculated separately for both control and study groups. The $\chi^{2}$-test was used to identify percentage difference between the groups. Mann-Whitney U test was used to assess the possible statistically significant differences between the two groups, whereas KruskalWallis ANOVA was employed for more than two groups. Linear regression analysis was used to determine the possible correlation between QFT-GIT and TST results.

To define the influence of selected predictor variables (age, sex, immune diseases, other diseases, smoking, alcohol consumption, and contact with tuberculosis) on the dependent variable (QFT-GIT, TST), multiple regression analysis and general regression model (GRM) were used. Pareto distribution diagram was used to show GRM results in T value. Statistical significance at 0.05 level was used in all methods.

\section{Results}

The incidence of immune system diseases was equally distributed in subjects with positive QFT-GIT and TST. Rheumatoid arthritis was the most prevalent disease in both QFT and TST positive subjects (38.67\% QFT positive and 40\% TST positive), followed by Crohn's disease (24\% QFT positive and 23.33\% TST positive), whereas other diseases were less frequent. Adalimumab was the most prescribed biological therapy (Table 1).

Among QFT positive subjects, $80.67 \%$ were also TST positive (Table 2), whereas $2.67 \%$ of QFT negative respondents had positive TST results. Linear regression analysis revealed a very good correlation between QFT-GIT and TST results $(\mathrm{R}=0.74 ; \mathrm{p}=$ 0.000000).

Thirty percent of study subjects and $10 \%$ of control subjects had a history of tuberculosis contact. The percentage of patients with tuberculosis contact was significantly lower in the control group $\left(\chi^{2}=14.2 ; \mathrm{p}=\right.$ 0.0002).

Tuberculosis contact as a risk factor had a statistically significant effect on QFT-GIT and TST results. Seventy-five percent of respondents with a history of tuberculosis contact had positive QFT-GIT test results, while $80 \%$ had positive TST results. In the QFT positive group, 25 of 45 subjects with a history of tuberculosis contact had moderate reaction (firm bump
Table 1. Biological therapy distribution in study (QFT positive) and control (QFT negative) groups

\begin{tabular}{|l|l|l|l|l|}
\hline \multirow{2}{*}{ Biological therapy } & \multicolumn{2}{|l|}{ Study group } & \multicolumn{2}{l|}{ Control group } \\
\cline { 2 - 5 } & $\mathrm{n}$ & $\%$ & $\mathrm{n}$ & $\%$ \\
\hline Tocilizumab & 5 & 3.33 & 7 & 4.67 \\
Etanercept & 45 & 30.00 & 47 & 31.33 \\
Adalimumab & 72 & 48.00 & 72 & 48.00 \\
Golimumab & 3 & 2.00 & 13 & 8.67 \\
Infliximab & 23 & 15.33 & 8 & 5.33 \\
Rituximab & 2 & 1.33 & 3 & 2.00 \\
\hline
\end{tabular}

QFT $=$ QuantiFERON test

Table 2. Distribution of respondents considering TST results in study (QFT positive) and control (QFT negative) groups

\begin{tabular}{|c|c|c|c|c|}
\hline \multirow{2}{*}{ TST test } & \multicolumn{2}{|c|}{ Study group } & \multicolumn{2}{|c|}{ Control group } \\
\hline & $\mathrm{n}$ & $\%$ & $\mathrm{n}$ & $\%$ \\
\hline $\begin{array}{l}\text { Negative reaction } \\
\text { (no firm bump } \\
\text { at the test site) }\end{array}$ & 29 & 19.33 & 146 & $97.33^{*}$ \\
\hline $\begin{array}{l}\text { Moderate positive } \\
\text { reaction (firm bump } \\
\text { of } 5 \mathrm{~mm}(0.2 \text { in.) } \\
\text { in size) }\end{array}$ & 99 & 66.00 & 4 & $2.67^{*}$ \\
\hline $\begin{array}{l}\text { Strong positive } \\
\text { reaction } \\
\text { (firm bump of } 10 \mathrm{~mm} \\
\text { ( } 0.4 \text { in.) in size) }\end{array}$ & 22 & 14.67 & 0 & 0 \\
\hline
\end{tabular}

TST = tuberculin skin test; QFT = QuantiFERON test; *statistically significant difference between control and study groups considering TST results

of $5 \mathrm{~mm}$ (0.2 in.) in size), 19 subjects had strong reaction (firm bump of $10 \mathrm{~mm}$ (0.4 in.) in size), and only one subject had no reaction during TST testing (no firm bump at the test site). The Kruskal-Wallis ANOVA test and Mann-Whitney U test results (Table 3) showed that the variables of age, smoking and tuberculosis contact had a statistically significant impact on the QFT-GIT and TST results.

Regression analysis confirmed a statistically significant correlation between the selected predictor variables and QFT-GIT test results $(\mathrm{R}=0.55$; $\mathrm{p}=$ $0.000002)$. Beta coefficient values indicated the variables of tuberculosis contact $(\beta=0.23 ; \mathrm{p}=0.000152)$, subject age $(\beta=0.21 ; p=0.001415)$ and smoking habit 
Table 3. Kruskal-Wallis ANOVA test and Mann-Whitney $U$ test results shown as $p$ values for QFT-GIT and TST, for selected dependent variables

\begin{tabular}{|l|l|l|}
\hline Variable & QFT-GIT test & TST test \\
\hline Age & $0.0001^{*}$ & $0.0163^{*}$ \\
Sex & 0.4192 & 0.9292 \\
Immune disease & 0.7650 & 0.8192 \\
Other diseases & 0.0752 & 0.1728 \\
Smoking & $0.0070^{*}$ & $0.0010^{*}$ \\
Alcohol consumption & 0.0619 & 0.0540 \\
Tuberculosis contact & $0.0000^{*}$ & $0.0000^{*}$ \\
\hline
\end{tabular}

QFT-GIT = QuantiFERON-TB Gold In-Tube test; TST = tuberculin skin test; *statistically significant difference $(\mathrm{p}<0.05)$

$(\beta=0.11 ; p=0.048893)$ to have by far greatest statistically significant effect on QFT-GIT test results.

A statistically significant correlation was also confirmed between the same predictor variables and TST results $(\mathrm{R}=0.71 ; \mathrm{p}=0.000000)$. Tuberculosis contact $(\beta=0.47 ; p=0.000000)$, subject age $(\beta=0.15 ; p=0.016634)$ and smoking habits had the greatest, statistically significant contribution to the overall correlation.

After one-year study period, $4 \%$ of subjects from the study group experienced conversion of QFT-GIT test from positive to negative, whereas all QFT negative subjects remained negative. According to the regression model results, none of the selected predictor variables had a statistically significant impact on QFT-GIT test negativization after chemoprophylaxis.

After six-month and one-year period, all subjects had normal clinical, radiological and microbiological findings of sputum, regardless of chemoprophylaxis and biological therapy.

\section{Discussion}

It is important to establish accurate diagnosis of latent tuberculosis in patients suffering from inflammatory autoimmune diseases during TNF- $\alpha$ antagonist therapy due to the high risk of its progression to an active form and an increased risk of developing some of the more complicated forms of tuberculo$\operatorname{sis}^{1,3,5}$.

Based on the QFT-GIT test results, subjects in this study were divided into two groups; $80.67 \%$ of the QFT positive subjects had positive TST results, indi- cating good correlation between QFT-GIT and TST results.

In the majority of other studies, greater difference between QFT-GIT and TST results has been documented $^{2,5,15-17}$. Such a difference, which favors QFTGIT test performance, appears to be due to the falsepositive TST results because of previous BCG immunization and due to false-negative TST results in immunocompromised patients s, $^{2,15-17}$.

In this study, the prevalence of the history of tuberculosis contact was significantly higher in the study group as compared with the control group (30\%:10\%). In the control, QFT negative group, only 15 subjects had tuberculosis contact. When TST was performed, only two subjects had moderate reaction, whereas 13 subjects had no reaction. Positive TST results in these two QFT negative patients who had a history of tuberculosis contact and in another two subjects with no history of tuberculosis contact but having TST positive and QFT-GIT negative results can be interpreted as a false-positive TST result, which can occur due to previous BCG immunization and cross-reactivity with non tuberculosis mycobacteria, but not to the extent reported from other studies where this difference was much greater ${ }^{2,5,6,15-17}$.

Hsia et al. ${ }^{5}$ documented that positive TST result was 3 -fold higher in BCG-vaccinated than in unvaccinated patients, while the proportion of patients with positive QFT-GIT test results was only 1.5 -fold higher in BCG-vaccinated compared with unvaccinated patients. In this study, all patients were BCG-vaccinated. It is important to mention that one-fifth of QFT positive patients in this group were TST negative. In this study, greater sensitivity of QFT-GIT test as compared to TST, although not statistically significant, was consistent with other so far documented studies, especially when it comes to immunocompromised patients ${ }^{1,2,5}$. Some of these studies have reported similar QFT-GIT test results between immunocompromised and healthy subjects, whereas positive TST results were significantly lower in immunocompromised patients when compared with healthy subjects ${ }^{5,10}$.

Although a large proportion of patients in our study were receiving methotrexate and other DMARDs, at the beginning of the study lower corticosteroid doses were used $(10 \mathrm{mg} /$ day $)$ and none of the patients received TNF- $\alpha$ antagonist therapy, so generally speaking, no patient had severe comorbid infection. 
Such immunosuppression did not appear to have a substantial effect on TST and QFT-GIT test results.

After six weeks of tuberculosis prophylaxis schemes used in this study (6 months of isoniazid), TNF- $\alpha$ antagonist therapy was introduced in QFT positive respondents. Among TNF- $\alpha$ antagonists, adalimumab was most frequently prescribed ( $48 \%$ of subjects), followed by etanercept (30\% of subjects).

On second clinical evaluation conducted six months after the first visit and during third clinical evaluation after one-year period, all physical examinations, chest radiographs and microbiological analysis for Mycobacterium tuberculosis (sputum culture 2 times) revealed normal findings in all patients included in the study. After one-year period, QFT-GIT test was performed again in all patients. Conversion to negative result was recorded in $4 \%$ of QFT positive subjects, while all QFT negative patients remained negative.

In the United Kingdom (UK), a risk-based strategy such as the BTS UK pre-anti-TNF- $\alpha$ guideline is recommended $^{18}$. This emphasizes clinical assessment, and balances the annual risk of developing active tuberculosis (using country of birth and age) against the chance of hepatotoxicity during treatment for LTBI. This guideline is in line with the low expected background prevalence of Mycobacterium tuberculosis in UK population, therefore QFT-GIT test results are more likely to be false than genuine true-positive in that kind of population ${ }^{19}$.

Although TNF- $\alpha$ antagonist candidates are expected to be at no greater risk of exposure to Mycobacterium tuberculosis than the background population in general, a higher risk of tuberculosis was previously observed among patients with rheumatoid arthritis treated with prednisolone and DMARDs ${ }^{3}$. In this study, rheumatoid arthritis was one of the most frequently present immune diseases with two-times higher incidence in women than in men. Therefore, performing QFT-GIT test in that kind of population remains fully justified.

Since the BTS guideline was published, the National Institute for Health and Clinical Excellence has issued a guideline discussing non-HIV associated cause of immunosuppression, although not specifically mentioning pre-TNF- $\alpha$ antagonist assessment. This recommends that screening should include QFT-GIT and/or TST in immunocompromised subjects ${ }^{20}$.
Greveson et al. ${ }^{1}$ found QFT-GIT testing to be more favorable than TST in low incidence population where most of the subjects experienced previous BCG immunization, thus avoiding false-positive TST results. This is consistent with our results, as all QFT negative but TST positive patients remained negative at the end of the study and, what is most important, did not experience tuberculosis although were administered anti TNF- $\alpha$ therapy without previous prophylaxis.

In our study, older age, history of contact with tuberculosis and smoking significantly influenced the QFT-GIT and TST results, pointing to the importance of good clinical examination and detailed medical history, which is in line with the UK pre-TNF- $\alpha$ antagonist guideline ${ }^{18}$.

In our analysis, QFT-GIT test showed somewhat greater sensitivity and specificity when compared with TST, however, without statistical significance, showing that there is no gold standard for LTBI diagnosis and that every case should be analyzed thoroughly. This includes complete medical evaluation and detailed medical history. However, unlike TST, QFT-GIT does not require re-visit and its interpretation is less vulnerable to reader error, making this test more favorable. Since the number of patients suffering from inflammatory autoimmune diseases in need of TNF- $\alpha$ antagonist is increasing in Croatia, a large cost-effectiveness evaluation should be performed. Nevertheless, patients should be informed regarding LTBI assessment, its implications and possible on-going risks.

\section{References}

1. Greveson K, Goodhand J, Capocci S, et al. Yield and cost effectiveness of mycobacterial infection detection using a simple IGRA-based protocol in UK subjects with inflammatory bowel disease suitable for anti-TNFa therapy. J Crohns Colitis. 2013;7:412-8. Epub 2012/09/24. doi: 10.1016/j.crohns.2012. 08.010 .

2. Danielsen AV1, Fløe A, Lillebaek T, Hoffmann HJ, Hilberg O. An interferon-gamma release assay test performs well in routine screening for tuberculosis. Dan Med J. 2014;61:A4856.

3. Winthrop KL, Iseman M. Bedfellows: mycobacteria and rheumatoid arthritis in the era of biologic therapy. Nat Rev Rheumatol. 2013;9:524-31. Epub 2013/06/25. doi: 10.1038/ nrrheum.2013.82.

4. Lee SK, Kim SY, Kim EY, et al. Mycobacterial infections in patients treated with tumor necrosis factor antagonists in 
South Korea. Lung. 2013;191:565-71. 4. Epub 2013/06/1. doi: 10.1007/s00408-013-9481-5.

5. Hsia EC, Schluger N, Cush JJ, et al. Interferon- $\gamma$ release assay versus tuberculin skin test prior to treatment with golimumab, a human anti-tumor necrosis factor antibody, in patients with rheumatoid arthritis, psoriatic arthritis, or ankylosing spondylitis. Arthritis Rheum. 2012;64:2068-77. doi: 10.1002/art. 34382.

6. Chang BI, Park HY, Jeon K, et al. Interferon- $\gamma$ release assay in the diagnosis of latent tuberculosis infection in arthritis patients treated with tumor necrosis factor antagonists in Korea. Clin Rheumatol. 2011;30:1535-41. Epub 2011/05/10. doi: 10.1007/s10067-011-1771-9.

7. Inanc N, Aydin SZ, Karakurt S, Atagunduz P, Yavuz S, Direskeneli H. Agreement between QuantiFERON-TB gold test and tuberculin skin test in the identification of latent tuberculosis infection in patients with rheumatoid arthritis and ankylosing spondylitis. J Rheumatol. 2009;36:2675-81. Epub 2009/11/16. doi: 10.3899/jrheum.090268.

8. Dinser R, Fousse M, Sester U, et al. Evaluation of latent tuberculosis infection in patients with inflammatory arthropathies before treatment with TNF-alpha blocking drugs using a novel flow-cytometric interferon-gamma release assay. Rheumatology (Oxford). 2008;47:212-8. doi: 10.1093/rheumatology/ kem351.

9. Greenberg JD, Reddy SM, Schloss SG, et al. Comparison of an in vitro tuberculosis interferon-gamma assay with delayed-type hypersensitivity testing for detection of latent Mycobacterium tuberculosis: a pilot study in rheumatoid arthritis. J Rheumatol. 2008;35:770-5. Erratum in: J Rheumatol. 2008 May;35(5):943.

10. Matulis GI, Jüni P, Villiger PM, Gadola SD. Detection of latent tuberculosis in immunosuppressed patients with autoimmune diseases: performance of a Mycobacterium tuberculosis antigen-specific interferon gamma assay. Ann Rheum Dis. 2008;67:84-90. Epub 2007/07/20.

11. Kobashi Y, Mouri K, Obase Y, Fukuda M, Miyashita N, Oka M. Clinical evaluation of QuantiFERON TB-2G test for immunocompromised patients. Eur Respir J. 2007;30:945-50. Epub 2007/07/25.
12. Ferrara G, Losi M, Meacci M, et al. Routine hospital use of a new commercial whole blood interferon-gamma assay for the diagnosis of tuberculosis infection. Am J Respir Crit Care Med. 2005;172:631-5. Epub 2005/06/16.

13. Meier T, Eulenbruch HP, Wrighton-Smith P, Enders G, Regnath T. Sensitivity of a new commercial enzyme-linked immunospot assay (T SPOT-TB) for diagnosis of tuberculosis in clinical practice. Eur J Clin Microbiol Infect Dis. 2005; 24:529-36.

14. Van Zyl-Smit RN, Zwerling A, Dheda K, Pai M. Within-subject variability of interferon- $\gamma$ assay results for tuberculosis and boosting effect of tuberculin skin testing: a systematic review. PLoS One. 2009;4:e8517. doi: 10.1371/journal.pone.0008517.

15. Grant J, Jastrzebski J, Johnston J, et al. Interferon-gamma release assays are a better tuberculosis screening test for haemodialysis patients: a study and review of the literature. Can J Infect Dis Med Microbiol. 2012;23:114-6.

16. Tiernan JF1, Gilhooley S, Jones ME, et al. Does an interferongamma release assay change practice in possible latent tuberculosis? QJM. 2013;106:139-46. Epub 2012/11/17. doi: 10.1093/ qjmed/hcs185.

17. Gunluoglu G, Seyhan EC, Kazancioglu R, et al. Diagnosing latent tuberculosis in immunocompromised patients measuring blood IP-10 production capacity: an analysis of chronic renal failure patients. Intern Med. 2015;54:465-72. Epub 2015/ 01/15. doi: 10.2169 /internalmedicine.54.3245.

18. Ledingham J, Wilkinson C, Deighton C. British Thoracic Society (BTS) recommendations for assessing risk and managing tuberculosis in patients due to start anti-TNF-\{alpha\} treatments. Rheumatology (Oxford). 2005;44:1205-6.

19. Solovic I, Sester M, Gomez-Reino JJ, et al. The risk of tuberculosis related to tumour necrosis factor antagonist therapies: a TBNET consensus statement. Eur Respir J. 2010;36:1185206. Epub 2010/06/7. doi: 10.1183/09031936.00028510.

20. National Institute for Health and Clinical Excellence. Tuberculosis. Clinical diagnosis and management of tuberculosis, and measures for its prevention and control. $2011 \mathrm{http} / /$ guidance. nice.org.uk/CG117/Guidance/pdf/English (accessed 29 ${ }^{\text {th }}$ February 2012). 
Sažetak

\title{
PRIMJENA QuantiFERON-TB Gold In-Tube TESTA U DIJAGNOZI LATENTNE TUBERKULOZE ZA VRIJEME PRIMJENE ANTAGONISTA TUMORSKE NEKROZE KOD OSOBA KOJE BOLUJU OD ARTRITISA
}

\author{
D. Baričević, S. Popović Grle, J. Morović Vergles, S. Čuković Čavka, M. Jakopović, G. Redžepi, Z. Boras, \\ M. Baričević i M. Samaržija
}

Cilj ovoga istraživanja bio je ispitati ulogu testa QuantiFERON-TB Gold In-Tube (QFT-GIT) u otkrivanju latentne tuberkuloze u imunokompromitiranih bolesnika prije terapije antagonistima tumor nekrotizirajućeg čimbenika alfa (TNF- $\alpha$ ). U istraživanju je sudjelovalo 300 ispitanika slične životne dobi. Ispitnu skupinu činilo je 150 ispitanika pozitivnih na testu QuantiFERON (QFT) koji su bolovali od reumatoidnog artritisa, Crohnove bolesti, ulceroznog kolitisa, ankilozantnog spondilitsa te psorijatičnog artritisa, dok je kontrolnu skupinu činilo 150 ispitanika negativnih na testu QFT koji su bolovali od istih bolesti. Od svih ispitanika uzeta je detaljna medicinska anamneza. Od dijagnostičkih testova učinjen je test QFT-GIT, kožni tuberkulinski test (TST), rtg pluća te sputum na Mycobacterium tuberculosis 2 puta. Pozitivan test QFT-GIT bez obzira na rezultate kožnog tuberkulinskog testa smatrao se indikacijom za liječenje latentne tuberkuloze. Rezultati ovoga istraživanja pokazali su dobru korelaciju između testova QFT-GIT i TST. Svi ispitanici ispitne skupine su za vrijeme provođenja profilakse i nakon njezina završetka te za vrijeme provođenja biološke terapije imali uredan klinički nalaz, uredan radiološki nalaz te negativan nalaz mikrobiološke analize sputuma. U ispitnoj skupini je 4\% ispitanika imalo konverziju pozitivnog testa QFT-GIT u negativan, dok su svi ispitanici negativni na testu QFT ostali negativni. Potvrđena je statistički značajna pozitivna korelacija između rezultata testova QFT-GIT i TST te životne dobi ispitanika, pušenja i kontakta s tuberkulozom. Rezultati pokazuju da je uz dobar klinički pregled i detaljnu anamnezu važno provesti testiranja kako bi se spriječila progresija bolesti odnosno profilaksa izonijazidom.

Ključne riječi: Tuberkulinski test; Latentna tuberkuloza - dijagnostika; Artritis; Tumorski nekrotički faktori - antagonisti $i$ inhibitori; Biološka terapija; Hrvatska 